\title{
RARE EARTH ELEMENT GEOCHEMISTRY AND PROTOLITHS OF SCHISTS IN SOUTHEAST, LOKOJA, CENTRAL NIGERIA.
}

\author{
BARTH N. EKWUEME and BASSEY E. EPHRAIM \\ (Received 21 September 2004; Revision accepted 24 November, 2004)
}

\section{ABSTRACT}

The Nigerian schist belts constitute the most important lithologic units necessary for the unravelling of the geochemical and geodynamic evolution of the basement complex. The schists have however undergone extensive alterations owing to weathering and metamorphism. REE abundance and distribution patterns of Lokoja schists indicate that the schist belts are metamorphosed shale-greywacke sequence. Their provenance possibly contained volcanogenic debris and the passive margin of the West African craton provided most of the materials. The reworking and metamorphism of the sediments took place during the Pan-African Orogeny ca. $687 \mathrm{Ma}$ ago.

KEYWORDS: Schists, Provenance, Reworking, Rare Earth Element, Evolution.

\section{INTROOUCTION}

Southeast L.okoja belongs to the Nigerian basement complex and is located around the confluence of Rivers Niger and Benue (Fig. 1). The Nigerian basement is situated in the Pan-African mobile zone lying between the West African craton and the Gabon-Congo craton. Lithologically, the basement is composed of a migmatite-gneiss complex. a metavolcano-sedimentary series or schist belts, which form a supracrustal cover on the former, and intrusive rocks of acidic, intermediate, basic and ultrabasic compositions (Klemm, et al., 1984).

The Nigerian schist belts, whose areal extent is still not well known, have received special attention. Descriptions and reviews of those located in the southwest and northwest of the country have been presented by Fitches et al. (1985), Affaton et al. (1991), and Elueze (1992). Until recently, it was thought that the schist belts occupy a N-S trending trough, which does not extend beyond latitude $8^{\circ} \mathrm{E}$. Schist belts have, however, been reported from southeast Nigeria (Ekwueme and Onyeagocha, 1986: and Toteu et al. (1987) believe that these ate extension of the Poli schists in Cameroon Republic.

Among the rock units in southeast Lokoja are schists whose field occurrence and petrography have been discussed by Ekwueme and Onyeagocha (1988) and Hockey et al. (1986). The schist belts of Nigeria have been compared to rocks of Archaean greenstone beits (Wright and McCurry, 1970; Hubbard, 1975, Klemm et al 1984; Ige and Asubiojo, 1991; Attoh and Ekwueme, 1997) and the understanding of the composition of these schists is crucial in unravelling the evolution of the basement complex. The discussion of the chemical composition of the schist belts has hitherto been based on major and trace elements (Ekwueme, 2003). Mcist of these schists are metamorphosed to amphibolite facies grade and have also undergone substantial weathering, rare earth elements are essential in determining their protoliths and petrogenesis since these elements are thought to be rarely affected in their distribution in rocks by those processes.

\section{GEOLOGIC SETTING}

Rock types in southeast Lokoja are schists, gneisses, ri.jmatites, granites, and gabbros (Fig. 1). Detailed descriptions of these rocks and their field relationships have been presented in Ekwueme and Onyeagocha (1988). A summary is given here.
The schists include (i) Quartz muscovite schist, (ii) Quartz muscovite biotite garnet schist, (iii) Staurolite garnet schist and, (iv) Cordierite garnet schist. The modal composition of these schists is shown in Table 1. The quartz muscovite schist is fine - medium grained and foliated. Metaquartzitic selvages are present possibly indicating a sandstone sequence of the original pre-metamorphic sedimentary rock. This rock is rich in muscovite and is consequently, light-coloured. The quartz muscovite biotite garnet schist is fine-to-medium grained and has foliation trending NW with dips varying from 15 to $20^{\circ} \mathrm{NE}$. It is dark in colour, reflecting the preponderance of biotite in the mode. The staurolite garnet schist is generally medium grained and textures become coarser towards the north (around EmiAndrew), where crystals of staurolite as long as $5 \mathrm{~cm}$ occur in the rock. This schist is light coloured and contains flakes of muscovite and garnet porphyroblasts. The rock is associated with metaquartzites, pointing to its possible sedimentary parentage. The cordierite garnet schist occurs as a narrow band running approximately $\mathrm{N}-\mathrm{S}$ in the middle of the map area (Fig. 1). It is medium to coarse grained and has been folded parallel to the foliation which trends NE - SW. Geophysical studies have revealed that the schists were emplaced in a NE - SW trending fractures (Madu and Onuoha, 1984). Thin bands of mica and quartz are observed to alternate in outcrops of this schist. Porphyroblasts of garnet are conspicuous in hand specimen and the emplacements of granite in the southern part of the cordierite garnet schist possibly triggered off boron metasomatism which resulted in the extensive lourmalization of the rock. Dips of foliation ranges from $25^{\circ}$ to $45^{\circ}$ mostly NW and foliations dipping in opposite directions (SE) points to occurrences of a synclinal structure. This has been confirmed by geophysical studies, and the axis lies $5.5 \mathrm{~km}$ west to Gboloko (Madu and Onuoha, 1984).

\section{MINERAL COMPOSITION}

The schists contain index minerals garnet, staurolite and cordierite (Table 1). Ekwueme (1983) and Onyeagocha and Ekwueme (1990) used these index minerals to place metamorphic isograds in Lokoja area. The mineral assemblages occurring in these schists (Table 1) indicate that the metamorphism was regional medium-pressure type and increased in grade from east to west. The schists were metamorphosed to grades ranging from upper grenschists to medium amphibolite. 


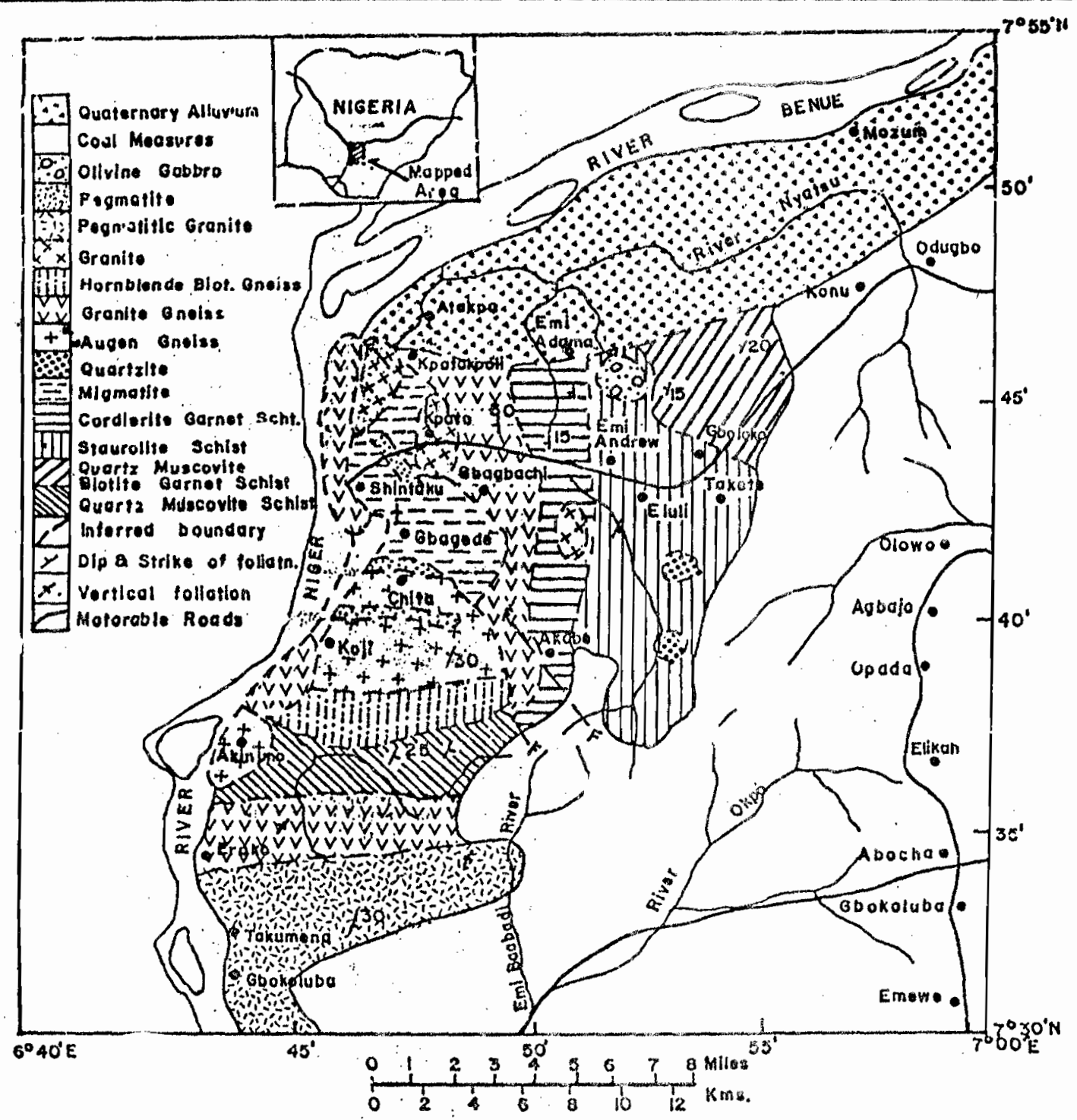

Fig 1: Geological Map of Southeast Lokoja, Nigeria (after Ekwueme, 1983).

TABLE 1: Average Modal composition of Schists in Southeast Lokoja.

\begin{tabular}{|l|l|l|l|l|}
\hline & "QMS & $\begin{array}{l}\text { QMB } \\
\text { GS } \\
(n=12)\end{array}$ & SGS & CGS \\
& 30 & 30 & 20 & 20 \\
\hline Quartz & $(n=15)$ & $(n=25)$ & $(n=20)$ \\
\hline Plagioclase & 15 & 10 & 5 & 5 \\
\hline K-feldspar & 20 & - & - & 12 \\
\hline Biotite & 2 & 35 & 20 & 25 \\
\hline Muscovite & 31 & 6 & 9 & 10 \\
\hline Chlorite & - & 15 & 10 & 5 \\
\hline Staurolite & - & - & 30 & - \\
\hline Cordierite & - & - & - & 10 \\
\hline Garnet & - & 2 & 2 & 5 \\
\hline Tourmaline & 1 & 2 & 4 & 6 \\
\hline Clinozoisite & 1 & - & - & 2 \\
\hline
\end{tabular}

*QMS = Quartz muscovite schist; $Q M B G S=$ Quartz muscovite biotite garnet schist; $S G S=$ Staurolite garnet schist; $C G S=$ Cordierite garnet schist.

\section{CHEMICAL COMPOSITION}

Whole-rock chemical analysis of representative samples of schists from southeast Lokoja was done by $X$-ray fluorescence following the method of Norrish and Hutton (1969). The rare earth element analysis was performed by optical emission spectroscopy (ICP-OES; ARL 3520) and the determination of REE contents was carried out after seoaration by ion exchange resirs. Samples SS2 and SS3 were anawyed by Instrumental Neutron Activation (INAA) at the $\mathbf{U} .8$. Geological Survey Laboratory in Reston. Other samples mere. analysed at the Geochemical Laboratory, Institut für Geclogio. Technical University of Braunschweig, Germany. The results of the analysis are shown in Table 2, 3 and 4.

\section{Major and I race tlements}

The schists are characterized by high $\mathrm{SiO}_{2}$ (up to $75 \%$ ) and $\mathrm{Al}_{2} \mathrm{O}_{3}$ (up to 20\%) (Table 2). The $\mathrm{Al}_{2} \mathrm{O}_{3} /\left(\mathrm{Na}_{2} \mathrm{O}+\right.$ $\mathrm{K}_{2} \mathrm{O}+\mathrm{CaO}$ ) is greater than one, and the Niggli al is also greater than Niggli (alk $+c$ ). These parameters reflect the aluminium-rich nature of the parent rocks, resulting in the formation of staurolite and cordierite during the metamorphism. The $\mathrm{TiO}_{2}$ content is, however, high when compared to values expected in clay-rich sediments, and only quartz muscovite schist and staurolite garnet schist (SS3) have $\mathrm{TiO}_{2} / \mathrm{Al}_{2} \mathrm{O}_{3}$ 
TABLE 2: Average Major Element Composition (in \%) of schists in Southeast Lokoja

\begin{tabular}{|c|c|c|c|c|c|c|}
\hline & QMS & QMBGS & SGS1 & SGS2 & 5653 & CGS \\
\hline $\mathrm{SiO}_{2}$ & 75.04 & 62.26 & 62.89 & 69.57 & $56.80^{\circ}$ & 63.13 \\
\hline $\mathrm{TiO}_{2}$ & 0.47 & 0.95 & 1.05 & 0.96 & 0.99 & 0.91 \\
\hline $\mathrm{Al}_{2} \mathrm{O}_{3}$ & 13.47 & 16.13 & 17.02 & 14.23 & 20.44 & 17.19 \\
\hline $\mathrm{Fe}_{2} \mathrm{O}_{3}$ & 3.01 & 7.57 & 7.54 & 5.71 & 9.31 & 7.06 \\
\hline MnO & 0.01 & 0.17 & 0.15 & 0.12 & 0.11 & 0.16 \\
\hline $\mathrm{MgO}$ & 0.57 & 3.61 & 4.06 & 2.55 & 3.74 & 3.23 \\
\hline $\mathrm{CaO}$ & 0.17 & 1.77 & 1.44 & 1.72 & 1.32 & 1.80 \\
\hline $\mathrm{Na}_{2} \mathrm{O}$ & 0.34 & 3.45 & 2.86 & 2.87 & 1.57 & 2.46 \\
\hline $\mathrm{K}_{2} \mathrm{O}$ & 5.59 & 2.79 & 2.49 & 2.03 & 3.30 & 2.66 \\
\hline $\mathrm{P}_{2} \mathrm{O}_{5}$ & 0.10 & 0.24 & 0.04 & 0.16 & 0.23 & 0.27 \\
\hline $\mathrm{H}_{2} \mathrm{O}$ & 0.10 & 0.13 & 0.18 & 0.13 & 0.21 & 0.11 \\
\hline LOI & 1.62 & 0.91 & 1.45 & 1.01 & 1.15 & 0.83 \\
\hline Total & 100.49 & 99.98 & 101.17 & 101.06 & 99.17 & 99.81 \\
\hline \multicolumn{7}{|c|}{ Nigali Values } \\
\hline $\mathrm{al}$ & 56 & 38 & 40 & 41 & 45 & 42 \\
\hline $\mathrm{im}$ & 14 & 33 & 36 & 30 & 35 & 32 \\
\hline 6 & 2 & 8 & 6 & 9 & 6 & 8 \\
\hline alk & 28 & 21 & 17 & 20 & 14 & 17 \\
\hline si & 535 & 249 & 252 & 339 & 215 & 264 \\
\hline$k$ & 0.92 & 0.35 & 0.36 & 0.32 & 0.58 & 0.41 \\
\hline$m g$ & 0.42 & 0.65 & 0.68 & 0.63 & 0.61 & 0.64 \\
\hline . & 323 & 65 & 84 & 159 & 59 & 96 \\
\hline
\end{tabular}

"See explanation for Table $1 ;$ * Total $\mathrm{Fe}$ as $\mathrm{Fe}_{2} \mathrm{O}_{31}$ "* $\mathrm{LOI}=$ loss on ignition.

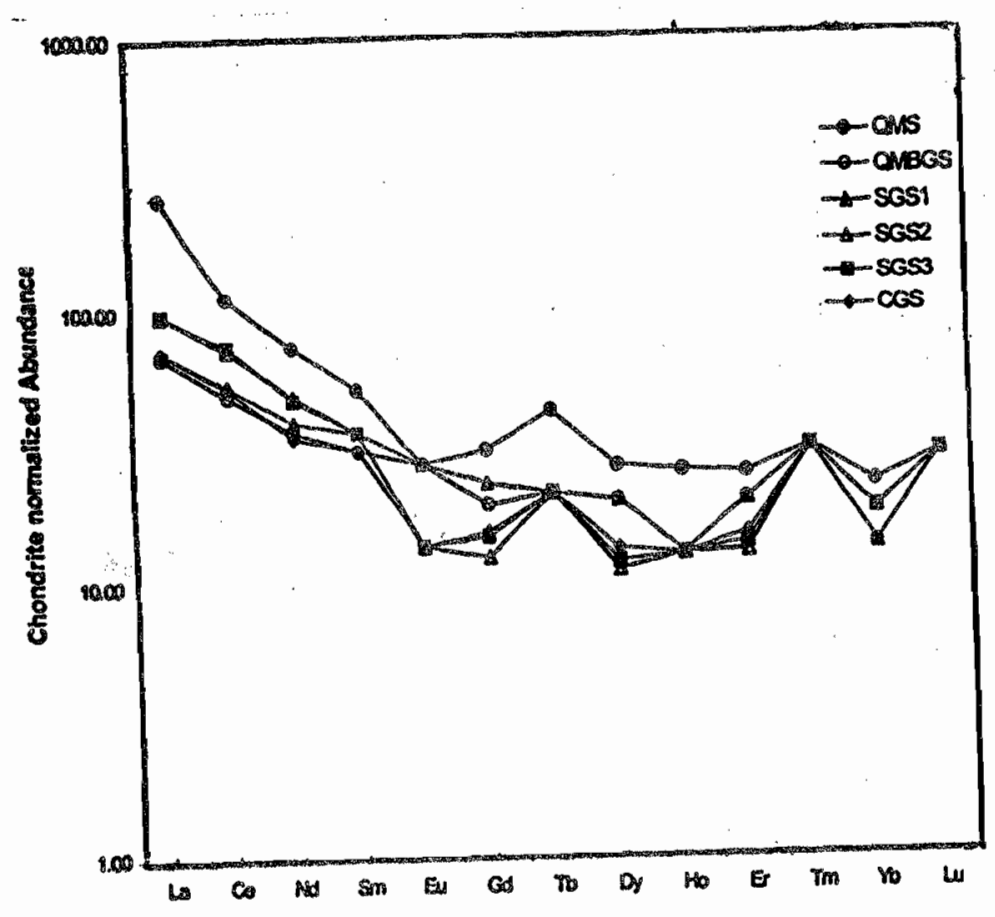

Fig. 2: Rare earth elements (Rockf chondrites) plot for schists in Southeast Lokoja

ratios approximately equal 100.040 expected in clays. Other schists in the area have higher $\mathrm{TiO}_{2} / \mathrm{Al}_{2} \mathrm{O}_{3}$ ratios, and this is indicative of sediments contaminated by basic to intermediate volcanic components (Spears and Kanaris-Sotirious, 1976). $\mathrm{K}_{2} \mathrm{O} / \mathrm{Na}_{2} \mathrm{O}$ is variable in the schists (Table 2). Some samples have $\mathrm{K}_{2} \mathrm{O}$ greater than $\mathrm{Na}_{2} \mathrm{O}$. which is characteristics of pelites and semipelites, whereas others have $\mathrm{Na}_{2} \mathrm{O}$ greater than $\mathrm{K}_{2} \mathrm{O}$ which characterizes greywackes (Pettijohn, 1975). Taylor and Mclennan (1985) noted that $\mathrm{K}_{2} \mathrm{O} / \mathrm{Na}_{2} \mathrm{O}$ ratio less than one is also characteristic of volcanogenic greywackes. The variation of $\mathrm{K}_{2} \mathrm{O} / \mathrm{Na}_{2} \mathrm{O}$ ratio in metasediments has been at. (i) the mixed nature or association of two composttionally different lithologic units e.g. shale-greywacke sequence as parent rock. (ii) facies changes and (iii) addition of materials through metasomatism. The first case is most likely for the Lokoja schists.

The $\mathrm{Al}_{2} \mathrm{O}_{3} / \mathrm{Na}_{2} \mathrm{O}$ ratio is a maturity indes for sediments. Mature sediments have values of 10 or more. For mature greywackes, the value is 4.8. Most samples of Lokoja schists have values greater than 4.8 but less than 10 (Toble 2), indicating that they were mostly immature sediments. Some samples (SS1 and CGS) have values between 5 and 6. which indicate igneous provenance. The fact that some samples of quartz muscovite schist and staurolite gamet schist have values greater than 10 . suggest that sections of the sedimentary sequence did attain maturity.

The mixed nature of the pre-metamorphic lithology of the Lokoja schists is also reflected in the trace element contents (Table 3), which is variable in the same rock unit. $\mathrm{Cr}$ is rather. high in all samples except quartz muscovite schist. This is indicative of the metasedimentary nature of the schists (Condie, 1967; Argast and Donnelly, 1986). The Rb content is higher than the value of 60 and $30 \mathrm{ppm}$ quoted for shales and greywackes respectively (Taylor, 1965). They are closer to the values of $100 \mathrm{ppm}$ given for high-Ca granites (Turekian and Wedepohl, 1961). The Sr content is also similar to that of highCa granites (El Bouselly and EI Sokkary. 1975).

\section{REE Composition and Discussion}

Girty et al. (1993) agree with McLonnan of (1990). Taylor and McLennan (1985), Condie (1991) and McLennan and Taylor (1991) that the REEs, Th and Sc are carried in the solid load during transportation from source rocks to final site of deposition and that because of their low solubility in most natural waters, these elements are relatively immobilo during weathering, transportation and diagenesis and are therefore. transferred-from source areas to sites of deposition in 
TABLE 3: Average Trace Element Composition (ppm) of Schists in Southeast Lokoja

\begin{tabular}{|c|c|c|c|c|c|c|}
\hline & "QMS & $\begin{array}{r}Q M B G \\
S\end{array}$ & SGS1 & SGS2 & $\overline{S G S 3}$ & CGS \\
\hline As & 7 & 1 & $\overline{-}$ & 4 & 4 & 15 \\
\hline$B a$ & 729 & 404 & 665 & 311 & 477 & 587 \\
\hline co & 88 & 67 & 90 & 51 & 58 & 87 \\
\hline $\mathrm{Cr}$ & 1 & 106 & 105 & 127 & 84 & 103 \\
\hline C.t. & 13 & 25 & 27 & 81 & 81 & 19 \\
\hline Ga & 13 & 12 & 20 & 11 & 10 & 14 \\
\hline Mo & 6 & 7 & 10 & 5 & 3 & 5 \\
\hline$N B$ & 19 & 9 & 9 & 7 & 9 & 7 \\
\hline Ni & 4 & 64 & 75 & 29 & 71 & 53 \\
\hline$P b$ & 8 & 23 & 10 & 15 & 20 & 15 \\
\hline$R B$ & 229 & 96 & 80 & 71 & 77 & 86 \\
\hline$S C$ & 4 & 16 & 19 & 27 & 27 & 17 \\
\hline$s r$ & 49 & 207 & 197 & 175 & 95 & 204 \\
\hline$T_{h}$ & 35 & 3 & 1 & 5 & 5 & 1 \\
\hline$U$ & 4 & 2 & 3 & 4 & 3 & 3 \\
\hline V & 10 & 119 & 153 & 88 & 88 & 143 \\
\hline$\gamma$ & 50 & 30 & 32 & & & \\
\hline $2 n$ & 15 & 46 & 112 & 71 & 81 & 133 \\
\hline \multicolumn{7}{|c|}{ Rare Earth Elements } \\
\hline Lá & 92 & 23 & 24 & 33 & 33 & 24 \\
\hline $\mathrm{Ce}$ & 103 & 44 & 48 & 65 & 67 & 47 \\
\hline Nd & 47 & 23 & 25 & 31 & 30 & 22 \\
\hline $\mathrm{Sm}$ & 10 & 6 & 7 & 7 & 7 & 6 \\
\hline$E u$ & 2 & 2 & 2 & 1 & 1 & 1 \\
\hline$G d$ & 8 & 5 & 6 & 3 & 4 & 4 \\
\hline$T b$ & 2 & 1 & 1 & 1 & 1 & 1 \\
\hline$D_{y}$ & 8 & 6 & 6 & 3 & 4 & 4 \\
\hline Ho & 2 & 1 & 1 & 1 & $\imath$ & 1 \\
\hline Er & 5 & 4 & 4 & 3 & 3 & 1 \\
\hline $\mathrm{Tm}$ & 1 & 1 & 1 & 1 & 1 & 1 \\
\hline$y b$ & 5 & 3 & 3 & 4 & 4 & 3 \\
\hline Lus & 1 & 1 & 1 & 1 & 1 & 1 \\
\hline
\end{tabular}

* See explanation for Table 1

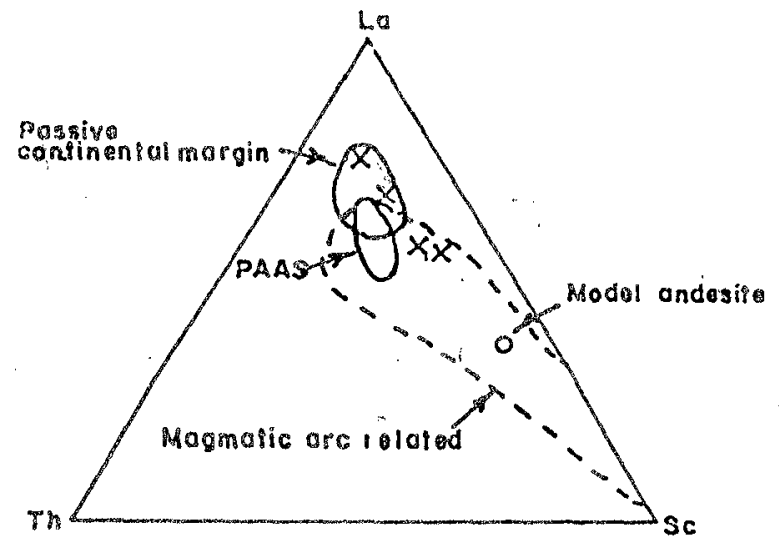

Fig. 3: La - Th- Sc ternary plot of schists of S sutheast Lokoja (after McLennan and Taylor, 1985 and McLerinan et al., 1990 unchanging proportions. The rare earths, $\mathrm{Sc}$ and Th are not affected greatly by metamorphism (McLennan, 1989; Taylor and McLennan, 1985), thus their composition in a metamorphosed clastic rock should be representative of the average composition of their source rocks. This is in contrast to other elements such as $\mathrm{K}, \mathrm{Na}, \mathrm{Ca}, \mathrm{U}, \mathrm{Fe}, \mathrm{Mn}, \mathrm{Rb}, \mathrm{Pb}$ and $\mathrm{Sr}$ which are fractionated to varying degrees during weathering. transport, diagenesis and metamorphism (McLennan, 1989). Murray et al. (1990) have also shown that REE abundance and relative fractionation are indicators of depositional environment.

Schists in southeast Lokoja are enriched in both LREE and HREE (Tables 3 and 4) when compared to the average values given by Condie (1991) for Archaean and Early Proterozoic continental crust. This may reflect the younger age of the Lokoja schists since. the REE abundance appears to increase with decreasing age. The REE distribution patterns of all the schists (Fig. 2) are characterized by variable LREE $E_{N}$ values $\left(\operatorname{La}_{N}=71-270 ; \mathrm{Ce}_{\mathrm{N}}=48-113\right)$, a welldeveloped Eu anomaly (Eu/EuN $=0.55-0.98$ ) and a fairly uniform range of HREE contents $(Y b=14-23)$ (Table 4). The REE patterns (Fig. 2) are similar to those reported for shales and greywackes (McLennan and Taylor, 1991; Yaowanoiyothin and Barr, 1991; Girty ef al., 1993). The patterns are also similar to those shown by North Arnerican metamorphosed shale components (Gromet et al., 1984) and average shales (Condie, 1991). The fan-shaped arrangement of the single REE spectra as shown by the Lokoja schists (Fig. 2) has been interpreted as an indication of systematic and progressive depletion of the REE ( $L a_{N} / Y b_{N}$ ranges from 4.96 to 11.91) (Stähle, et al., 1987). The increase in $\mathrm{La}_{N} / \mathrm{Yb}_{\mathrm{N}}$, ratios, i.e. depletion of HREE, is connected, according to Stähle, et al. (1987), with an increase of $\mathrm{SiO}_{2}$ and a decrease of $\mathrm{Zr}$. This is true for the Lokoja schists. The depletion in HREE may be due to dissolution of zircon during metamorphism since zircon is the most important phase for concentrating the HREE (Henderson, 1984). The decrease of apatite as indicated by $\mathrm{P}_{2} \mathrm{O}_{5}$ contents (Table 2) may contribute to the general depletion in the REE.

The chondrite-normalized REE distribution patterns for the Lokoja schists (Fig. 2) display no systematic change as a result of varying metamorphic grade. They show light-REE enrichments trends and negative Eu anomalies. McLennan ot al. (1990) and Girty et al. (1993) have reported similar REE distribution patterns including Eu anomalies that vary from 0.58 to 1.08 and 0.46 to 0.93 respectively for sediments from passive continental margins. These range values compare favourably with 0.55 and 0.98 obtained for the Lokoja schists.

Samples of the Lokoja schists were plotted on a Lam Th-Sc ternary diagram (Fig. 3) of McLennan and Taylor (1985) and McLennan et al. (1990). The quarzz mica schist and staurolite garnet schists plot in the field of passive continental margin, whilst the quartz muscovite biotite garnet schist and cordierite garnet schist plot in the magmatic arc related field. The iatter field overlaps a part of post Archaean Australian shale field. It is therefore evident that the protoliths of the schists came from a provenance composed of sediments containing some igneous rocks debris. A mixture of shale and greywacke is the most likely pre-metamorphic rock. The REE pattern is very similar to those of greywacke-shale turbidites of Proterozoic age (McLennan and Taylor, 1991). Since the patterns for shales are similar to those of their sources, it is concluded that the protoliths were derived from continental sources, most likely the West African craton and Congo craton.

The composition of schists in southeast Lokoja have also been plotted on various discriminatory/classification diagrams (Ekwueme, 2003). All the schists cluster around average Proterozoic shales in the $\mathrm{SiO}_{2} / \mathrm{Al}_{2} \mathrm{O}_{3}$ versus $\mathrm{K}_{2} \mathrm{O}$ / $\mathrm{Na}_{2} \mathrm{O}$ diagram of Cameron and Garrels (1980). They however plot in the field of shale and greywacke in the ACF diagram. 
TABLE 4: REE Ahundances expressed as rock/chondrite ratios for Schists of Southeast Lokoja

\begin{tabular}{|c|c|c|c|c|c|c|}
\hline & QMS & QMBGS & SGS1 & SGS2 & SGS3 & CGS \\
\hline $\mathrm{La}$ & 270.59 & 67.65 & 70.59 & 97.06 & 97.06 & 70.59 \\
\hline $\mathrm{Ce}$ & 113.19 & 48.35 & 52.75 & 71.43 & 73.63 & 51.65 \\
\hline Nd & 73.44 & 35.94 & 39.06 & 48.44 & 46.88 & 34.38 \\
\hline $\mathrm{Sm}$ & 51.28 & 30.77 & 35.90 & 35.90 & 35.90 & 30.77 \\
\hline Eu & 27.40 & 27.40 & 27.40 & 13.70 & 13.70 & 13.70 \\
\hline$G d$ & 30.77 & 19.23 & 23.08 & 12.58 & 14.77 & 15.38 \\
\hline $\mathrm{Tb}$ & 42.55 & 21.28 & 21.28 & 21.28 & 21.28 & 21.28 \\
\hline Dy & 26.67 & 20.00 & 20.00 & 11.20 & 12.03 & 13.33 \\
\hline Ho & 25.64 & 12.82 & 12.82 & 12.82 & 12.82 & 12.82 \\
\hline Er & 25.00 & 20.00 & 20.00 & 13.00 & 14.00 & 15.00 \\
\hline $\mathrm{Tm}$ & 31.25 & 31.25 & 31.25 & 31.25 & 31.25 & 31.25 \\
\hline$Y b$ & 22.73 & 13.64 & 13.64 & 18.18 & 18.18 & 13.64 \\
\hline Lu & 29.41 & 29.41 & 29.41 & 29.41 & 29.41 & 29.41 \\
\hline La/Lu & 9.20 & 2.30 & 2.40 & 3.30 & 3.30 & 2.40 \\
\hline $\mathrm{La} / \mathrm{Sm}$ & 5.28 & 2.20 & 1.97 & 2.70 & 2.70 & 2.29 \\
\hline $\mathrm{La} / \mathrm{Yb}$ & 11.91 & 4.96 & 5.18 & 5.34 & 5.34 & 5.18 \\
\hline $\mathrm{Ce} / \mathrm{Sm}$ & 2.21 & 1.57 & 1.47 & 1.99 & 2.05 & 1.68 \\
\hline $\mathrm{Eu} / \mathrm{Eu}^{*}$ & 0.78 & 0.98 & 0.98 & 0.68 & 0.55 & 0.55 \\
\hline
\end{tabular}

Metagreywacke are derived from igneous rocks of basic to intermediate composition (Argast and Donnelly, 1986). A plot of the composition of th metagreywackes of Lokoja schists on $\mathrm{CaO}-\mathrm{K}_{2} \mathrm{O}-\mathrm{Na}_{2} \mathrm{O}$ agram show that they were possibly derived from granodiorite protoliths. The major, trace and rare earth elements of the quartz muscovite biotite garnet schist and cordierite garnet schists compare favourably with that of granodiorite reported in Cox el al. (1979), which is the same rock as the high-Ca granite of Turekian and Wedepohl (1961).

$\mathrm{Rb}-\mathrm{Sr}$ whole rock isochron age of $687 \pm 13 \mathrm{Ma}$ was oktained on the schist of Lokoja area (Caen-Vachette and Ekwueme, 1988). This indicates that the rocks were metamorphosed during the Pan-African Orogeny. Schists of similar age and composition occur in northwestern Nigeria. which is not far from the Lokoja area (Fitches et al., 1985). It is possible that the Lokoja schists are southward extension of the schist belts in northwestern Nigeria.

\section{CONCLUSIONS}

Shale-greywacke sequence is the most probable protoliths of the Lokoja schists. This is also the inferred protoliths of schists in other parts of Nigeria (Rahaman, 1376; Ekwueme and Onyeagocha, 1986; Imeokparia and Emofurieta, 1991). The REE abundance and patterns indicate that the shale-greywacke sequence was derived from continental provenance containing basic-intermediate igneous rocks. The West African and Congo cratons could have provided the pre-metamorphic rocks.

\section{REFERENCES}

Affaton, P., Rahaman, M. A., Trompette, R. and Sougy, J., 1991. The Dahomeyide Orogen: tectonothermal evolution and relationships with the Volta Basin. In: R. D. Dallmeyer and J. P. Lécorché (eds.), The West African Orogen and Circum-Atlantic Correlatives. Springer Verlag, Berlin. pp. $107-122$.

Argast, S. and Donnelly, T. W., 1986. Compositions and sources of sediments in the upper Dhawer Supergroup, South India. J. Geol., 94: 215-231.

Attoh, K. and Ekwueme, B. N., 1997. Greenstone belts of the West African shield. In J. M. de Wit and L. Ashwal (eds.), Tectonic Evolution of Greenstone belts. Oxford University Press.

Caen-Vachette, M and Ekwueme, B. N., 1988. Rb-Sr ages of schists in the metasedimentary belts of southeast Lokoja and their implication for the Precambrian evolution of Central Nigeria. J. Afr. Earth Sci., (1): 121-126.

Cameron, E. M. and Garrels R. M., 1990. Geochemical composition of some Precambrian shales from the Canadian shield. Chem. Geol., 28: 181 - 197. . 
Condie, K. C., 1991. Another look at rare earth elements in shales. Geochim. Cosmochim. Acta, 55: 2527 2531.

Cox, K. G., Bell, J. D. and Pankhurst, R. J., 1979. The interpretation of igneous rocks. George Allen and Unwin, London, 450p.

Ekwueme, B. N., 1983. Regional metamorphism of pelitic rocks of Southeast Lokoja, Nigeria, J. Min. Geol., 20: $71-77$

Ekwueme, B. N., 2003. Petrogenesis of schist in Southeast Lokoja, Central Nigeria. Global Journal of Geological Sciences, 1 (1): 29- 42.

Ekwueme, B. N., and Onyeagocha, A. C., 1986 Geochemistry of metasedimentary rocks of Uwet area, Oban massif, SE Nigeria. Geol. Rundsch., 75 (2): $411-420$.

Ekwueme, B. N., and Onyeagocha, A. C., 1988. Plagioclase in metamorphosed rocks of Lokoja Southeast, Nigeria. J. Afri. Earth Sci., 7: 887 - 894 .

Elueze, A. A., 1992. Rift system for Proterozoic schist belts in Nigeria. Tectonophysics, 209: $167-169$.

El Bouselly, A. M. and El Sokkary, A. A., 1975. The relation between $\mathrm{Rb}, \mathrm{Ba}$ and $\mathrm{Sr}$ in granitic rocks. Chem. Geol., 16: $207-219$

Fitches, W. R., Ajibade, A. C., Egbuniwe, 1. G., Holt, R. W. and Wright, J. B., 1985. Late Proterozoic schist belts and plutonism in NW Nigeria. J. Geol. Soc. London, 142: 319 - 337

Girty, G. H., Hanson, A. D., Yoshinobu, A. S., Knaack, C., and Johnson, D., 1993. Provenance of Palaeozoic mudstones in a contact metamorphic aureole determined by rare earth element. Th and $3 \mathrm{c}$ analy:, Merre Nevada, California. Geology, 21: $363 \ldots \ldots$

Gromet, L. P., Dymek, R. F., Haskin, L. A and Korotov, R. L., 1984. The North American shale composite: its compilation, major and trace element characteristics. Geochim. Cosmochim Acta, 48: $2469-2482$

Henderson, P., 1984. Rare Earth Element Geochemistry. Elsevier, Amsterdam, 510p.

Hockey, R. D., Sacchi, R., De Graaff, W. P, F., H. and Muotoh, E. O. G., 1986. The geology of Lokoja Auchi. Geol. Surv. Nigerian Bull. 39, 71pp.

Hubbard, F. H., 1975. Precambrian crustal developments in Western Nigeria: Indication from the Iwo region. Geol. Soc. Am. Bull., 86: 548 - 554.

Ige, O. A. and Asubiojo, O. I., 1991. Trace element geochemistry and petrogenesis of some metaultramafites in Apomu and Ife-llesha areas of southwestern Nigeria. Chem. Geol., 91: 19-32.
Imeokparia, E. G. and Emofurieta, W. O., 1991. Protoliths and petrogenesis of Precambrian gneisses from Igbeti area, SW Nigeria. Chem Erde., 51: 39 - 54

Klemm, D. D., Schneider, W., and Wagner, B., 1984. The Precambrian metavolcanosedimentary sequence east of Ife and llesha, SW Nigeria. J. Afri. Ea, th Sci., 2:161 - 176

Madu, A. J. C. and Onuoha, K. M., 1984. Aeromagnetic anomalies, gravity and ground magnetic studies in parts of the basement complex. Benue state Nigeria. $20^{\text {th }}$ Ann. Conf. Nigerian Min. Geosci. Soc. (Nsukka, Nigeria), Abstract Vol., p. 34

McLennan, S. M., 1989. Rare earth elements in sedimentary rocks: Provenance and sedimentary processes. Mineral. Soc. Am. Reviews in Mineral., 21: 169 200

McLennan, S. M., and Taylor, S. R., 1991. Sedimentary rocks and crustal evolution: tectonic setting and secular trends. J. Geol., 99: 1 - 21 .

McLennan, S. M., Taylor, S. R., McCulloch, M. T. and Maynard, J. B., 1990. Geochemical and $\mathrm{Nd}-\mathrm{Sr}$ isotope compositions of deep-sea turbidites. crustal evolution and plate tectonic associations. Geochim. Cosmochim. Acta, 54: $2015-2050$.

Murray, R. W., Buchholtzten, M. R., James, D. C., Gerlash, D. C and Russ, G. P. 1990. Rare earth elements as indicators of different marine depositional environments in cherts and shales. Geology, 18: $268-271$

Norrish, K. and Hutton, J. T., 1969. An accurate X-ray spectrographic method for the analysis of a wide range of geological samples. Geochim. Cosmochim Acta., 33: 431 - 453

Onyeagocha, A. C. and Ekwueme, B. N., 1990 Temperature-Pressure distribution patterns in metamorphosed rocks of the Nigerian basement complex- a preliminary analysis. J. Afri. Earth Sci. 11: $83-93$.

Pettijohn, F. J., 1975. Sedimentary Rocks. $3^{\text {rd }}$ edition, Harper and Row, New York, 628p.

Rahaman, M. A., 1976. Progressive polyphase metamorphism in pelitic schists around Aiyetoro, Oyo State, Nigeria. J. Min. Geol., 12: 33 - 44

Spears, D. A. and Kanaris-Sotirious, R., 1976. Titanium in some Carboniferous sediments from Great Britain. Geochim. Cosmochim. Acta, 40: 345 - 351.

Stähle, H. J., Raith, M., Hoernes, S. and Delfs, A., 1987. Element mobility during incipient granulite formation at Kabbaldurga, Southern India. J. Petrol, 28: 803834.

Taylor, S. R., 1965. The application of trace element data to problems of petrology. In: M. L. Ahrens, F. Press, S. K. Runcorn and C. Urey (eds.), Physics and Chemistry of the Earth. Pergamon, Oxford, 6: 133214. 
Taylor: S. R. and McLennan, S. M., 1985. The Continental Crust: Its Composition and Evolution. Blackwell, Oxford, 312p.

Toteu, S. F., Michard, A., Bertrand, J. M. and Rocci, G., 1987. U/Pb dating of Precambrian rocks from Northern Cameroon, orogenic evolution and chronology of the Pan-African belt of Central Africa. Precambrian Res, 37: 71-87.

Turekian, K. K., and Wedepohl, K. H., 1961. Distributicn of the elements in some major units of the earth crust. Geol. Soc. Am. Bull., 72: 175 - 192.

Wright, J. B., and McCurry, P., 1970. A reappraisal of some aspects of Precambrian shield geology: Discussion. Geol. Soc. Am. Bull., 81: 3491 - 3492.

Yaowanoiyothin, W. and Barr, S. M., 1991. Petrology of the Black Brook granitic suite, Cape Breton Island, Nova Scotia. Canad. Minera., 29: 499 - 515. 